\title{
Impact of Foreign Direct Investment on Trade Balance: Evidence from Cote d'Ivoire
}

\author{
Yaya Keho ${ }^{1}$ \\ ${ }^{1}$ Ecole Nationale Supérieure de Statistique et d'Economie Appliquée (ENSEA) Abidjan, Côte d'Ivoire \\ Correspondence: Yaya Keho, Ecole Nationale Supérieure de Statistique et d'Economie Appliquée (ENSEA) \\ Abidjan, 08 BP 03 Abidjan 08, Côte d'Ivoire. Tel: 225-2244-4124. E-mail: yayakeho@ yahoo.fr
}

Received: April 30, 2020

Accepted: June 9, 2020

Online Published: June 28, 2020

doi:10.5539/ijef.v12n7p113

URL: https://doi.org/10.5539/ijef.v12n7p113

\begin{abstract}
Foreign direct investment (FDI) inflows have been increasing in developing countries over the past decades. However, there is only a few evidence about their impact on the trade balance on the recipient countries. This study empirically examines the issue for Cote d'Ivoire from 1980 to 2017. To that end, we extend the traditional trade balance function to include FDI and employ alternative cointegration testing and estimation methods. The results show that domestic income, real effective exchange rate and foreign direct investment are important drivers of trade balance. A real depreciation of domestic currency improves the trade balance both in the long and short run, thus consistent with Marshall-Lerner condition. Furthermore, FDI adversely affects trade balance in the long run.
\end{abstract}

Keywords: foreign direct investment, trade balance, income, exchange rate, Cote d'Ivoire

JEL Classification: C32, F10, F21, O24.

\section{Introduction}

Foreign direct investment (FDI) inflows to developing countries have been increasing over the past decades. They have become the largest source of external finance that may help them to bridge the technology gap, improve productivity and increase export performance. Thus, FDI inflows have been shown to play a key role in improving economic growth (see, De Mello, 1997; Borensztein et al., 1998; Hoang et al., 2010; Gui-Diby, 2014; Mohammad \& Mahmoud, 2014; Shahzad et al., 2015; Nwaogu \& Ryan, 2015). Based on these evidence, developing countries are implementing various incentives to attract more FDI. FDI is believed to be an important factor of economic development, particularly for African countries facing a large resource gap. However, FDI may have significant negative effects on the host country's macroeconomic stability. In this study, we are interested in the effects that FDI could have on the trade balance of the host country. The relationship between FDI inflows and trade balance is not clear-cut. Conventional wisdom believes that FDI plays a role in improving trade balance in the long run. This view is drawn from the export-promoting effects of FDI. FDI stimulates exports by accumulating capital to foster the production of exportable goods and allowing transfer of new technology and new products for exports. On the other hand, FDI may have negative effects on trade balance through increased imports. This is particularly the case when multinational firms tend to import high-technology machines as well as intermediate inputs which increase the host country imports. This increase in import demand negatively affects the trade balance, leading to negative consequences for the host country's balance of payments (Helpman, 1984; Markusen \& Venables, 1998). FDI inflows may also affect negatively the balance of payments when a large share of gross domestic product is repatriated abroad in the form of profits and dividends. Increased FDI inflows may become a threat to exchange rate stability, with adverse consequences for exports. Conversely, if foreign firms use local raw materials and other inputs to produce exportable goods or goods that were imported earlier, they may have significant improvement effect on trade balance. Given the role of foreign direct investment and trade in economic growth, the relationship between both variables appears to be a significant topic of research. In this study, we are interested in estimating the overall effect of FDI inflows on trade balance rather than its differential impact on exports and imports.

To the best of our knowledge, no study has investigated the effect of FDI on the trade balance in Cote d'Ivoire. This study tries to fill the gap in the empirical literature. The aim is to examine whether trade balance is adversely affected by FDI inflows. Besides that, Cote d'Ivoire provides an interesting case study for several 
reasons. First of all, Cote d'Ivoire has experienced remarkable economic growth of about $8.8 \%$ over the period from 2012 to 2017. It has improved the business climate through a number of reforms, including dematerialization of services and administrative acts, introduction of an online platform to pay taxes, adoption of a new investment Code, establishment of a one-stop shop for business creation and establishment of online complaints debit at the Commercial Court. Consequently, the country is among the top ten reforming countries in the world and remains a preferred destination of foreign direct investment in West Africa. FDI inflows to Cote d'Ivoire grew at an average rate of $16.2 \%$ over the period from 2012 to 2017. In 2017, FDI inflows reached \$675 million, representing an increase of $17 \%$ compared to 2016. In the same time, FDI inflows to Sub-Saharan Africa fell by $27 \%$ in 2017 to $\$ 29.6$ trillion from $\$ 40.4$ trillion. Over the same period, trade surplus of Cote d'Ivoire decreased by $10.7 \%$. In 2017, trade surplus fell by $20 \%$. The increase in FDI inflows combined with the decrease in trade surplus raises the question about the relationship between foreign direct investment and trade balance in Cote d'Ivoire. Do FDI inflows in Cote d'Ivoire deteriorate or improve its trade balance? Is there a causal relationship between FDI inflows and trade balance? This study attempts to address these questions empirically.

The remainder of the study proceeds as follows. Section 2 reviews the empirical literature regarding the relationship between FDI and trade balance. Section 3 presents the empirical model, data description and the econometric methodology of the study. The empirical results are presented and discussed in Section 4. Section 5 concludes the study and provides some key policy recommendations.

\section{Literature Review}

The benefits and costs of foreign direct investment (FDI) have been a matter of intense debate in the economic literature. On the one hand, FDI is encouraged due to transfer of technology, expansion of trade, creation of jobs and promotion of economic growth. On the other hand, FDI is supposed to create balance of payments problems through capital outflows in the form of profits and dividends. In recent years, a number of research focused on the impact of FDI on host country's trade performance. The evidence from this literature is quite mixed and findings are still inconclusive. Some studies have supported that inward FDI positively affects trade, while some others have reported adverse trade effects that may be associated with such strong reliance on multinational investment, and still others found no significant relation between the two variables. For example, Lin (1995) examines the trade effects of foreign direct investment (FDI) between Taiwan and four ASEAN countries (Indonesia, Malaysia, the Philippines, and Thailand). The results show that Taiwan's outward FDI exerts a significant positive effect on exports to and imports from the host country, whereas no such effects were consistently found for inward FDI from the same country. Therefore, it can be inferred that inward FDI is neutral to trade in Taiwan. De Mello and Fukasaku (2000) examine the relationship between foreign trade and foreign direct investment (FDI) in selected Latin American and Southeast Asian economies in the period 1970-1994 by means of bivariate vector error-correction models and causality analysis. They find that the impact of FDI on the trade balance is stronger in trade-oriented economies, and that net FDI inflows are more sensitive to changes in exports in Southeast Asian countries, than in their Latin American counterparts, given the export-orientation of foreign investment in the former region. Liu et al. (2002) explore the link between trade, economic growth and inward foreign direct investment in China over the period from 1981:1 to 1997:4. The study finds the existence of a substitution effect between FDI and import. They also report one way causal link running from FDI to imports over the period. Alguacil and Orts (2003) investigate the link between inward foreign direct investment and imports in Spain. Their findings show that FDI exerts a positive effect on imports, suggest a complementary relationship between the two variables. Concerning the direction of causality, the results indicate the existence of a unidirectional causality running from FDI to imports. Yousuf et al. (2008) highlight the impact of FDI on exports and imports of Pakistan during the period 1973 to 2004. The results suggest that FDI has positive impact on real exports and real imports in the long run. In the short run, FDI has positive impact on imports and negative impact on exports. Hailu (2010) determines the relationship between FDI and trade balance of 16 African countries for the period from 1980 to 2007. Using the Least Square Dummy Variable (LSDV) regression method, he reports that FDI stock has positive effects on both exports and imports. The overall net effect of FDI on trade balance was inferred to be positive. Waheed and Jawaid (2010) study the impact of inward foreign direct investment (FDI) on aggregate imports in Pakistan over the period from 1981 to 2007. The results suggest that there exists a significant positive relationship between FDI and imports both in the short and long run. The causality result shows unidirectional causality running from inward FDI to aggregate imports in the country. Sajid and Nguyen (2011) use of a gravity model to examine the impact of FDI on exports, imports and net export in Vietnam for the period 1990-2007. The empirical analysis reveals that FDI has positive impact on both exports and imports. However, the impact of FDI on net-exports is insignificant during the full sample period. Soo et al. (2013) examine the relationship between trade, inward and outward FDI in Malaysia for the period from 1991 to 
2009. Their findings reveal that a positive relationship between inward FDI and trade, while outward FDI and trade linkages are not significant. Tran and Dinh (2014) examine the effects of FDI inflows on external imbalances in the developing and transition countries in Asia during the period 1991-2011. They find that FDI inflows worsen the trade balance first and then improve it. Chantha et al. (2018) estimate an import demand function for Cambodia over the period 1993-2015. Applying the Autoregressive Distributed Lag (ARDL) model, the study finds that foreign direct investment has an insignificant impact on import demand.

Regarding the effect of FDI on exports, the evidence is also mixed. While some found that increased levels of FDI positively affect exports (e.g., Lin, 1995; Zhang \& Song, 2000; Liu et al., 2001; Dritsaki et al., 2004; Kutan \& Vuksic, 2007; Xuan \& Xing, 2008; Bhatt, 2013), others reported evidence that FDI has insignificant or even negative effect on exports (e.g., Hsiao \& Hsiao, 2006; Jayachandran \& Seilan, 2010; Kiran, 2011; Dritsaki \& Stiakakis, 2014). There is evidence that FDI inflows improve trade balance (Anwar \& Nguyen, 2011). Some even discovered a negative effect of FDI on trade balance (e.g., Hailu, 2010; Tran \& Dinh, 2014), while others found FDI to be neutral to trade balance (Lin, 1995). Finally, Keho (2020) investigates the impact of inward foreign direct investment (FDI) on import demand in Cote d'Ivoire over the period from 1980 to 2017. Using the ARDL bounds testing approach, he finds that domestic income and FDI inflows have positive and significant effects on imports. This finding suggests that FDI could have a negative impact on the balance of trade of Cote d'Ivoire.

From these empirical studies no inference can be made about the impact of FDI inflows on trade performance. Most empirical studies have examined the impact of FDI on imports or exports. Accordingly, few attention has been devoted to the net impact of FDI on the trade balance of the recipient countries. The nature of the relationship between FDI and trade balance remains very much an open empirical issue. This study takes the issue to be of great importance and contributes to the empirical literature by examining the case of a small open African economy.

\section{Model, Data and Methodology}

\subsection{Empirical Model}

In this study, we estimate the trade balance model in a reduced form that would allow us to evaluate the overall effect of FDI on trade balance rather than isolating its differential impact on exports and imports. For this purpose, we rely on the following econometric model:

$$
\operatorname{lnTB} B_{t}=\beta_{0}+\beta_{1} \ln Y_{t}+\beta_{2} \ln R E R_{t}+\beta_{3} \ln F D I_{t}+\mu_{t}
$$

where $\ln$ represents natural logarithm, TB is trade balance on goods and services, $\mathrm{Y}$ is gross domestic product, RER is real effective exchange rate, FDI is foreign direct investment inflows, and $\mu_{t}$ is assumed to be a white-noise process.

The expected sign of the coefficient on domestic income is ambiguous, because an increase in domestic output increases both imports and exports. It depends upon whether domestic income represents the level of economic activity or a supply variable measuring the supply of exportable goods. The positive sign on the domestic income implies that an increase in domestic income leads to an improvement in trade balance in the long run. We expect domestic income to be negatively related to the trade balance since imports are positively related to domestic income. Real effective exchange rate is a key variable reflecting the country's competitiveness. Its effect on trade balance is ambiguous. Under the conventional Marshall-Lerner theory, a real depreciation of the domestic currency will stimulate exports and reduce imports, leading to an improvement in trade balance in the long run. Therefore, this theory predicts a negative effect of real effective exchange rate on trade balance. The effects of FDI on trade balance is also ambiguous. Increases in foreign investment may increase the home country's capacity of exportable goods and hence improve its trade balance. On the other hand, FDI may increase imports and worsens the trade balance. In this study, we are concerned with estimating the responsiveness of the trade balance to changes in foreign direct investment inflows to Cote d'Ivoire.

\subsection{Data}

To investigate the relationship between foreign direct investment and trade balance in Cote d'Ivoire, we use four variables. The two main variables of the study are trade balance (TB) and foreign direct investment inflows as percentage of GDP (FDI). The remaining two control variables are real effective exchange rate (RER) $(2010=100)$ and real GDP. The real effective exchange rate variable is such that an increase (decrease) represents a real appreciation (real depreciation) of the domestic currency. Usually trade balance is measured by the difference of total exports and total imports. In this study, trade balance was defined as the ratio of exports to imports. This ratio or its inverse has been used in a number of empirical studies (e.g., Bahmani-Oskooee, 1991; 
Guptar-Kapoor \& Ramakrishnan, 1999; Baharumshah, 2001; Onafowora, 2003; Ogbonna, 2016). This measure allows expressing the trade balance variable in logarithm form regardless of whether exports are greater or less than imports. An increase in this ratio indicates an improvement in trade balance. Any factor that increases imports will decrease trade balance while any factor that stimulates exports will increase trade balance. Data on real GDP and trade balance were obtained from the World Development Indicators of the World Bank. Data on FDI inflows were extracted from the data base of the United Nations Conference on Trade and Development (UNCTAD) and data on real effective exchange rate were sourced from the Central Bank of West African States (BCEAO). The data sample of the study covers the period from 1980 to 2017.

The descriptive statistics of the logarithmic transformation of the variables are displayed in Table 1 . The correlation matrix shows a negative relationship between real effective exchange rate and trade balance, implying that the two variables vary in opposite directions. This suggests that a real depreciation of domestic currency is associated with an improvement in trade balance. On the contrary, the correlation between trade balance and real GDP and between trade balance and FDI is positive but not significant at the 5 percent level. A major limitation of correlation analysis is that it does not take into consideration the effects of other control variables. Does any significant relationship exist between trade balance and FDI after controlling for domestic income and real effective exchange rate?

Table 1. Descriptive statistics and correlation matrix

\begin{tabular}{|c|c|c|c|c|}
\hline Variables & $\ln \mathrm{TB}$ & $\ln Y$ & lnRER & $\operatorname{lnFDI}$ \\
\hline \multicolumn{5}{|c|}{ Panel A: Summary statistics } \\
\hline Mean & 4.760 & 29.939 & 4.632 & 0.106 \\
\hline Median & 4.761 & 29.957 & 4.613 & 0.327 \\
\hline Maximum & 4.986 & 30.552 & 4.887 & 1.793 \\
\hline Minimum & 4.421 & 29.651 & 4.342 & -1.828 \\
\hline Std. dev. & 0.125 & 0.230 & 0.134 & 0.780 \\
\hline Skewness & -0.562 & 0.936 & 0.369 & -0.655 \\
\hline Kurtosis & 4.037 & 3.344 & 2.442 & 3.293 \\
\hline Jarque-Bera & 3.709 & 5.743 & 1.358 & 2.857 \\
\hline Probability & 0.156 & 0.056 & 0.507 & 0.239 \\
\hline \multicolumn{5}{|c|}{ Panel B: Correlation matrix } \\
\hline $\ln \mathrm{TB}$ & $1.000^{*}$ & & & \\
\hline $\ln Y$ & 0.009 & $1.000^{*}$ & & \\
\hline lnRER & $-0.464^{*}$ & $-0.324^{*}$ & $1.000^{*}$ & \\
\hline $\operatorname{lnFDI}$ & 0.202 & $0.508^{*}$ & $-0.583^{*}$ & $1.000^{*}$ \\
\hline
\end{tabular}

Note. TB, Y, RER, and FDI denote trade balance, real GDP, real effective exchange rate, and foreign direct investment inflows as share of GDP, respectively. (*) indicates statistical significance at the $5 \%$ level.

Figure 1 plots the pattern of trade balance and FDI inflows as share of GDP. As can be seen, the two variables have been oscillating over the sample period. After an upward sloping trend from 1981 to 1985, trade balance records a sharp decrease up to 1993 and reaches a pic in 1994, the year of the devaluation of the country's currency. After this year, trade balance oscillates and reaches a pic in 2002. From 2011, trade balance exhibits a declining trend. With respect to FDI inflows, they were stable over the sub-period 1980-1991 and then showed an increasing trend up to 1998. FDI inflows are declining from 1999 to 2011 with an average of $1.74 \%$ of GDP. It is worth mentioning that over this period, Cote d'Ivoire experienced economic hardship and social unrest. The slowdown in FDI inflows between 1999 and 2011 is the consequence of this crisis. With the end of the war in 2011, the country embarked on an economic recovery program which led to significant increase in foreign direct investment inflows. FDI inflows to Cote d'Ivoire represented 1.42\% of GDP over the period 2012-2017.

Trade balance (\%)

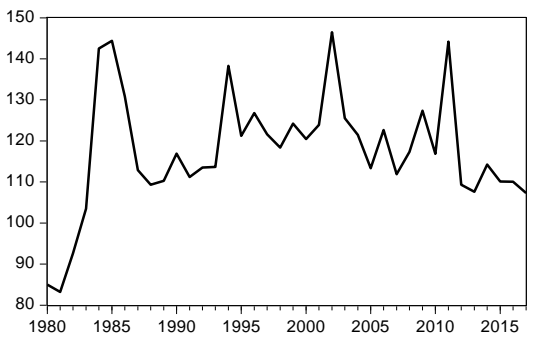

FDI (\% of GDP)

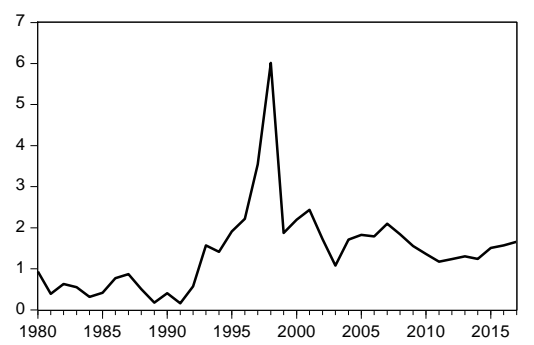

Figure 1. Trade balance and FDI inflows to Cote d'Ivoire over the period 1980-2017 
The sectoral composition of FDI inflows to Cote d'Ivoire is unequal. It shows that service sector has received considerable amounts of FDI in recent years. From 2014 to 2017, FDI inflows were mainly oriented on services which accounted for almost $46 \%$ of the total FDI inflows, followed by the primary sector with $36 \%$ and the manufacturing sector for $18.4 \%$. Foreign direct investment inflows are mainly oriented towards mining, telecommunication, financial intermediation and insurance. These subsectors have attracted about $65 \%$ of the total FDI inflows over the period 2014-2017.

Table 3. Foreign direct investment by sectors (as share of total FDI inflows)

\begin{tabular}{|c|c|c|c|c|c|}
\hline & 2014 & 2015 & 2016 & 2017 & 2014-2017 \\
\hline Primary Sector & 36.0 & 30.9 & 39.6 & 38.0 & 36.1 \\
\hline Agriculture, Forestry and Fishing & 0.4 & 0.0 & 0.9 & 0.2 & 0.4 \\
\hline Mining & 35.6 & 30.9 & 38.7 & 37.8 & 35.7 \\
\hline Manufacturing Sector & 27.2 & 16.9 & 18.7 & 10.9 & 18.4 \\
\hline Manufacturing & 27.2 & 16.9 & 18.7 & 10.9 & 18.4 \\
\hline Services Sector & 36.8 & 52.2 & 41.6 & 51.1 & 45.5 \\
\hline Electricity, Gas & 5.0 & 6.4 & 1.0 & 2.4 & 3.7 \\
\hline Water distribution, Sanitation & 0.0 & 0.0 & 0.0 & 0.0 & 0.0 \\
\hline Construction & 2.2 & 2.8 & 2.0 & 2.1 & 2.3 \\
\hline Wholesale and Retail & 4.6 & 3.8 & 6.9 & 1.4 & 4.2 \\
\hline Transport and Storage & 4.6 & 3.4 & 2.8 & 3.4 & 3.5 \\
\hline Hotels, Restaurants & 0.3 & 0.3 & 2.8 & 4.0 & 1.8 \\
\hline Communication & 8.3 & 17.9 & 9.9 & 12.9 & 12.2 \\
\hline Financing and Insurance & 11.3 & 17.4 & 15.7 & 24.5 & 17.2 \\
\hline Real estate and business services & 0.1 & 0.1 & 0.1 & 0.4 & 0.2 \\
\hline Others & 0.5 & 0.1 & 0.5 & 0.0 & 0.3 \\
\hline TOTAL & 100.0 & 100.0 & 100.0 & 100.0 & 100.0 \\
\hline
\end{tabular}

The sectoral decomposition of FDI inflows plays a major role in the determination of trade balance and economic growth. FDI inflows into tradable sectors are likely to be associated with higher exports leading to improvement of the trade balance of the recipient country. In contrast, the concentration of those inflows in the non-tradable sectors (e.g., construction, transport, communication, real estate, and financial intermediation) may stimulate imports through demand for inputs and thus leading to a worsening of the trade balance. The positive effect of FDI on export performance is likely to hold when FDI is largely export-oriented. A number of studies found a positive relationship between export-oriented FDI and the host country's manufactured exports (Athukorala \& Menon, 1995; UNCTAD, 1999; Zhang \& Song, 2000). The high concentration of inward FDI in Cote d'Ivoire in the mining sector rather than in the manufacturing sector does not favor the diversification of the country's exports. As the technology employed in natural resource extraction is capital intensive, extractive industries have limited prospects for inclusive growth and employment creation (UNCTAD, 2005). Furthermore, FDI inflows in the mining sector are regarded to be associated with very limited spillover effects. Therefore, FDI inflows in extractive industries are not likely to contribute much to broad-based economic development. Diversification from the primary sector to manufacturing and services would be a key factor which could help spur economic growth and development in Cote d'Ivoire.

\subsection{Econometric Methodology}

The examination of the relationship between FDI and trade balance will be performed in three steps. First, we test for the order of integration of the time series using unit root tests. Second, we test for the existence of a long run relationship between trade balance and explanatory variables by means of cointegration tests. For this purpose, we employ the Autoregressive Distributed Lag (ARDL) bounds testing approach to cointegration developed by Pesaran et al. (2001). This approach has several advantages over other alternative methods such as the Engle and Granger (1987) two step residual-based procedure and the system-based reduced rank regression approach developed by Johansen and Juselius (1990). The first main advantage is that it can be used with a mixture of $\mathrm{I}(0)$ or $\mathrm{I}(1)$ explanatory variables. Hence, it eliminates the uncertainty associated with pre-testing unit root tests in small sample sizes. The second advantage is that it provides consistent estimates of the long-run coefficients even in the presence of endogenous regressors (Inder, 1993; Cheung \& Lai, 1993). Endogeneity is an important econometric issue when studying the nexus between FDI and trade. Indeed, as reviewed above, FDI impacts on trade performance. In the same time, trade openness plays a significant role in attracting FDI (Asiedu, 
2002; Neumayer \& De Soysa, 2005; Onyeiwu \& Shrestha, 2004; Kandiero \& Chitiga, 2006; Jaiblai \& Shenai, 2019; Boga, 2019). Finally, the ARDL bound test approach allows different variables to be assigned different lag-lengths as they enter the model.

Basically, the ARDL approach to cointegration involves estimating the following error correction model:

$$
\begin{aligned}
& \Delta \ln T B_{t}=\phi_{0}+\phi_{1} \ln T B_{t-1}+\phi_{2} \ln F D I_{t-1}+\phi_{3} Z_{t-1}+\sum_{i=1}^{m} \gamma_{1 i} \Delta \ln T B_{t-i}+ \\
& \sum_{i=0}^{n} \gamma_{2 i} \Delta \ln F D I_{t-i}+\sum_{i=0}^{p} \gamma_{3 i} \Delta Z_{t-i}+e_{t}
\end{aligned}
$$

where $\Delta$ is the difference operator and $Z_{t}=\left(\ln Y_{t}, \operatorname{lnRER} R_{t}\right)$. The presence of a long run relationship among the variables is tested by restricting coefficients of lagged level variables equal to zero. That is, the null hypothesis of no long run relationship is $\mathrm{H}_{0}: \phi_{1}=\phi_{2}=\phi_{3}=0$. This hypothesis is tested using an $F$-test. The asymptotic critical values are provided by Pesaran et al. (2001). If the F test statistic exceeds the upper critical value, we conclude that there is evidence of a long run relationship among the variables. If the $\mathrm{F}$ test statistic is below the lower critical value, we cannot reject the null hypothesis of no cointegration. If the test statistic lies between the bounds, a conclusive inference cannot be made without knowing the exact orders of integration of the regressors. The ARDL bounds testing procedure is sensitive to the selection of the lag structure $(m, n, p)$. In this study, maximum lag length on each variable was set to five and the optimal lag structure was selected on the basis of the Akaike Information Criterion (AIC). The model has been tested by the diagnostic tests that are serial correlation, normality and heteroskedasticity. The stability of the model has also been tested using the Brown et al. (1975) cumulative sum of recursive residuals (CUSUM) and the cumulative sum of squares of recursive residuals (CUSUMSQ).

The final step of our econometric analysis infers the causal relationship between FDI and trade balance. The Granger causality test is performed from the following Vector Error Correction Model (VECM):

$$
\begin{gathered}
\Delta \ln T B_{t}=\alpha_{1}+\sum_{j=1}^{p} \gamma_{1 j} \Delta \ln T B_{t-j}+\sum_{j=1}^{p} \varphi_{1 j} \Delta \ln F D I_{t-j}+\sum_{j=1}^{p} \delta_{1 j} \Delta Z_{t-j}+\lambda_{1} e c t_{t-1}+e_{1 t} \\
\Delta \ln F D I_{t}=\alpha_{2}+\sum_{j=1}^{p} \gamma_{2 j} \Delta \ln T B_{t-j}+\sum_{j=1}^{p} \varphi_{2 j} \Delta \ln F D I_{t-j}+\sum_{j=1}^{p} \delta_{2 j} \Delta Z_{t-j}+\lambda_{2} e c t_{t-1}+e_{2 t}
\end{gathered}
$$

where $p$ is the optimal lag length and $e c t_{t-1}$ is the error correction term obtained from the long run relationship. The optimal lag $p$ is determined by both the Akaike Information Criterion (AIC) and the Final Prediction Error (FPE). In small sample studies $(n<60)$ these criteria have been shown to be superior to other information criteria (Lutkepohl, 1991; Liew, 2004).

The VECM enables the identification of short and long run causality. The short run causality is examined by testing the significance of the coefficients of the lagged difference terms, while the long run causality is identified by testing the significance of the coefficients on the error correction terms. In terms of short run causality, foreign direct investment (FDI) does not Granger cause trade balance (TB) if the null hypothesis $\varphi_{1 j}=0$ (for all $j$ ) is not rejected. Similarly, trade balance (TB) does not Granger cause foreign direct investment (FDI) if the null hypothesis $\gamma_{2 j}=0$ (for all $j$ ) is not rejected. Short run causality is tested using Wald-statistic which has an asymptotic chi-square distribution. With regard to the long run causality, foreign direct investment (FDI) does not cause trade balance in the long run if the null hypothesis $\lambda_{1}=0$ is not rejected. Similarly, trade balance (TB) does not cause foreign direct investment (FDI) in the long run if the null hypothesis $\lambda_{2}=0$ is not rejected.

\section{Empirical Results}

As mentioned above an essential step in the time series analysis is to examine the orders of integration of the variables. To that purpose, we apply the PP test of Phillips and Perron (1988) and the KPSS test of Kwiatkowski et al. (1992). The results of these tests are reported in Table 2. According to them, all the variables are stationary after taking the first difference. Thus, there is a mixture of $\mathrm{I}(1)$ and $\mathrm{I}(0)$ of the regressors. Based on this result, the next step is to test for the existence of long run relationships among the variables. 
Table 2. Results of Unit Root Tests

\begin{tabular}{lccccc}
\hline & Level & & \multicolumn{2}{c}{ First difference } \\
\cline { 2 - 3 } \cline { 5 - 6 } Series & PP & KPSS & & PP & KPSS \\
\hline $\ln$ TB & -2.775 & 0.208 & & $-7.198^{*}$ & 0.324 \\
$\ln Y$ & 2.444 & $0.709^{*}$ & & $-3.081^{*}$ & 0.397 \\
$\ln$ RER & $-2.992^{*}$ & 0.279 & & $-6.452^{*}$ & 0.069 \\
$\ln$ FDI & -2.000 & 0.435 & & $-7.532^{*}$ & 0.061 \\
\hline
\end{tabular}

Note. TB, Y, RER, and FDI denote trade balance, real GDP, real effective exchange rate, and foreign direct investment inflows as share of GDP. The unit root tests have been performed under the model with intercept. 5\% critical values for PP and KPSS tests are -2.943 and 0.463 , respectively. * indicates the rejection of the null hypothesis at $5 \%$ level of significance.

The results of the ARDL bounds test are displayed in Table 3. The calculated F-statistics are compared against the critical values given in Pesaran et al. (2001) under the model with restricted intercept and no trend. The results show that a long run relationship exists among the variables when trade balance and GDP are used as dependent variables. In each case, the computed F-test statistic exceeds the upper critical value at 5\% and 10\% levels of significance. Furthermore, the ARDL models fulfill the classical linear regression model assumptions.

Table 3. Results of the ARDL Cointegration Test

\begin{tabular}{lllll}
\hline Model & F.stat. & Diagnostic tests & & Correlation \\
\cline { 3 - 5 } & & Normality & Heteroscedasticity & $1.494[0.221]$ \\
\hline $\mathrm{F}_{\mathrm{TB}}$ & $6.274^{*}$ & $0.244[0.885]$ & $16.990[0.150]$ & $1.894[0.401]$ \\
$\mathrm{F}_{\mathrm{Y}}$ & 2.989 & $0.416[0.812]$ & $22.937[0.347]$ & $1.102[0.397]$ \\
$\mathrm{F}_{\mathrm{FDI}}$ & $4.904^{*}$ & $1.292[0.523]$ & $26.685[0.371]$ & \\
\hline & Critical values & Upper bounds I $(1)$ & \\
\cline { 2 - 4 } & Lower bounds I $(0)$ & 4.66 & \\
\hline $1 \%$ & 3.65 & 3.67 & 3.20 \\
$5 \%$ & 2.79 & & & \\
$10 \%$ & 2.37 & & & \\
\hline
\end{tabular}

Note. $\mathrm{F}_{\mathrm{TB}}, \mathrm{F}_{\mathrm{Y}}$, and $\mathrm{F}_{\mathrm{FDI}}$ denote the F-test statistic of the bound test using as dependent variable trade balance, real GDP, and foreign direct investment, respectively. The model includes a dummy variable taking value 0 from 1980 to 1993 and value 1 from 1994 to 2017. Lag length on each variable is selected using the AIC criterion with maximum lag set to 5. Critical values are generated under the model with restricted intercept and no trend. Figures in [.] are $p_{-}$values. . ${ }^{*}$ and ${ }^{* *}$ indicate the rejection of the null hypothesis of no cointegration at $5 \%$ and $10 \%$ levels of significance, respectively.

The robustness of cointegration results is tested by applying the Johansen and Juselius (1990) multivariate cointegration test and the results are presented in Table 4. As can be seen, both the trace and maximum eigenvalue statistics support the existence of cointegrating relationships among the variables under study. Therefore, we can conclude that long run relationships exist between trade balance, foreign direct investment, domestic income and real effective exchange rate in the case of Cote d'Ivoire.

Table 4. Results of the Johansen and Juselius tests for Cointegration

\begin{tabular}{|c|c|c|c|c|c|}
\hline \multirow[b]{2}{*}{$\mathrm{H}_{0}$} & \multirow[b]{2}{*}{$\mathrm{H}_{1}$} & \multicolumn{2}{|c|}{ Trace Test } & \multicolumn{2}{|c|}{ Max- Eigen Test } \\
\hline & & Statistic & Prob. & Statistic & Prob. \\
\hline $\mathrm{r}=0$ & $\mathrm{r}=1$ & $69.556^{*}$ & 0.001 & $30.410^{*}$ & 0.028 \\
\hline $\mathrm{r} \leq 1$ & $r=2$ & $39.145^{*}$ & 0.017 & $21.963^{* *}$ & 0.055 \\
\hline $\mathrm{r} \leq 2$ & $\mathrm{r}=3$ & 17.181 & 0.125 & 13.256 & 0.124 \\
\hline $\mathrm{r} \leq 3$ & $\mathrm{r}=4$ & 3.925 & 0.388 & 3.925 & 0.423 \\
\hline
\end{tabular}

Note: $r$ indicates the number of cointegrating relations. The model includes a dummy variable taking value 0 from 1980 to 1993 and value 1 from 1994 to 2017. The lag length of the level VAR is one according to information criteria. Cointegration test was performed under the case II. ${ }^{*}$ and ${ }^{* *}$ indicate the rejection of the null hypothesis at the $5 \%$ and $10 \%$ levels of significance, respectively.

As the next step of our empirical analysis, we estimate the long run coefficients associated with each independent variable. For comparison purpose, we estimate the long run relationship using the ARDL approach of Pesaran et al. (2001), the Fully Modified OLS (FMOLS) method proposed by Phillips and Hansen (1990), and the Dynamic OLS (DOLS) technique suggested by Stock and Watson (1993). These three estimation methods 
account for the possible endogeneity among the variables in the form of simultaneity bias. The empirical results obtained by normalizing on trade balance are reported in Table 5 . They consistently show that domestic income (GDP) and foreign direct investment (FDI) have significant negative effects on trade balance in the long run. In other words, increases in domestic GDP and FDI inflows reduce the trade balance. The negative effect of domestic income supports the Keynesian theory that increase in domestic income also increases import demand for goods and services, thereby causing a deterioration of the trade balance. The negative effect of FDI on the trade balance may be explained by the dominance of nontradable services (construction, electricity, transport, communication, real estate, and financial intermediation) which are likely to increase import demand of inputs. The results further indicate that real effective exchange rate has a negative relationship with trade balance, implying that a decrease in real exchange rate (i.e. real depreciation of domestic currency) causes an improvement in trade balance in the long run. This finding suggests that the Marshall-Lerner condition holds for Cote d'Ivoire.

Table 5. Long run estimates

\begin{tabular}{|c|c|c|c|c|c|c|}
\hline \multirow[t]{3}{*}{ Regressor } & \multicolumn{4}{|c|}{ Dependent variable: $\ln \mathrm{TB}$} & & \\
\hline & \multicolumn{2}{|l|}{ ARDL } & \multicolumn{2}{|l|}{ FMOLS } & \multicolumn{2}{|l|}{ DOLS } \\
\hline & Coef. & t-stat. & Coef. & t-stat. & Coef. & t-stat. \\
\hline $\ln Y$ & $-0.118^{*}$ & -2.961 & $-0.169^{* *}$ & -1.684 & -0.164 & -1.059 \\
\hline $\operatorname{lnRER}$ & $-0.192^{* *}$ & -1.827 & $-0.298^{* *}$ & -1.742 & $-0.427^{* *}$ & -1.701 \\
\hline $\operatorname{lnFDI}$ & $-0.026^{*}$ & -2.383 & $-0.052^{* *}$ & -1.687 & -0.082 & -1.500 \\
\hline Constant & $9.173^{*}$ & 8.492 & $11.164^{*}$ & 4.046 & $11.579^{*}$ & 2.692 \\
\hline
\end{tabular}

Note. The model estimated is: $\ln \mathrm{TB}_{\mathrm{t}}=\beta_{0}+\beta_{1} \ln \mathrm{Y}_{\mathrm{t}}+\beta_{2} \operatorname{lnRER}{ }_{\mathrm{t}}+\beta_{3} \ln \mathrm{nDI}_{\mathrm{t}}+\mu_{\mathrm{t}}$. where TB, Y, RER, and FDI denote trade balance, real GDP, real effective exchange rate, and foreign direct investment inflows as share of GDP, respectively. The model includes a dummy variable taking value 0 from 1980 to 1993 and value 1 from 1994 to 2017. The asterisks ${ }^{*}$ and ${ }^{* *}$ denote statistical significance at the 5\% and $10 \%$ levels, respectively.

The existence of a long run relationship between the variables provides support for the estimation of the short run dynamics. The short run coefficients are presented in Table 6 . The coefficient on the lagged error term is highly significant with the expected negative sign, confirming the existence of a long run relationship among the variables. The results also show that domestic income has a negative and significant relationship with trade balance. This finding supports the "demand as driver" view that income increases encourage people to demand more foreign goods which in turn increases imports and thus worsens the trade balance. This result agrees with Adeniyi et al. (2011) who found a negative relationship between domestic income and trade balance in Ghana. The results further indicate that a rise in real exchange rate brings about a fall in the trade balance while FDI does not have significant effect on the trade balance in the short run. Therefore, in the short run trade balance is adversely affected by growth in domestic income and real effective exchange rate. Thus, the remarkable economic growth of about 8.8\% recorded by Cote d'Ivoire over the period from 2012 to 2017 has contributed to reduce the trade surplus of its balance of payments.

Table 6. Short run estimates

\begin{tabular}{lccc}
\hline Regressor & \multicolumn{3}{c}{ Dependent variable: $\Delta \operatorname{lnTB}$} \\
\cline { 2 - 4 } & Coef. & t-stat. & Prob. \\
\hline$\Delta \ln Y$ & $-1.113^{*}$ & -3.702 & 0.001 \\
$\Delta \ln R E R$ & $-0.265^{*}$ & -2.399 & 0.023 \\
$\Delta \operatorname{lnFDI}$ & -0.010 & -0.476 & 0.637 \\
Constant & 0.011 & 0.851 & 0.402 \\
ECT(-1) & $-0.921^{*}$ & -5.929 & 0.000 \\
\hline
\end{tabular}

Note. TB, Y, RER, and FDI denote trade balance, real GDP, real effective exchange rate, and foreign direct investment inflows as share of GDP, respectively. The asterisks * denotes statistical significance at the $5 \%$ level.

Overall, the empirical results of this study provide evidence consistent with the Marshall-Lerner condition in the long run. In the short run, both domestic income and real effective exchange rate adversely affect trade balance, indicating no J-curve effect in the case of Cote d'Ivoire. Our finding regarding the improving effect of real exchange rate depreciation on trade balance is consistent with many empirical studies (e.g., Bahmani-Oskooee \& Gelan, 2012; Abd-El-Kader, 2013; Igue \& Ogunleye, 2014; Ogbonna, 2016) but contradicts with others (e.g., 
Adeniyi et al., 2011; Akpansung \& Babalola, 2013; Ogundipe et al., 2013; Oyinlola et al., 2013; Ziramba \& Chifamba, 2014; Michael \& Emeka, 2017).

Table 7. Results of the Granger causality tests

\begin{tabular}{cccccc}
\hline & \multicolumn{5}{c}{ Direction of Granger Causality } \\
\cline { 2 - 5 } Variable & \multicolumn{3}{c}{ Short Run } & Long Run \\
\cline { 2 - 5 } & $\mathrm{TB}$ & $\mathrm{Y}$ & $\mathrm{RER}$ & FDI & $\mathrm{ECT}_{\mathrm{t}-1}$ \\
\hline $\mathrm{TB}$ & - & $1.471[0.225]$ & $0.210[0.646]$ & $1.014[0.313]$ & $-1.008^{*}[0.001]$ \\
$\mathrm{Y}$ & $0.837[0.360]$ & - & $0.495[0.481]$ & $0.439[0.507]$ & $0.021[0.846]$ \\
$\mathrm{RER}$ & $1.966[0.160]$ & $1.284[0.257]$ & - & $2.135[0.143]$ & $0.649^{* *}[0.068]$ \\
FDI & $0.409[0.522]$ & $0.200[0.654]$ & $1.318[0.250]$ & - & $0.949[0.617]$ \\
\hline
\end{tabular}

Note. TB, Y, RER, and FDI denote trade balance, real GDP, real effective exchange rate, and foreign direct investment inflows as share of GDP, respectively, ECT is the error correction term. The lag length of the VECM is one according to information criteria. $\chi^{2}$ statistics for Wald tests are reported here and the $p$-value are indicated in brackets. The asterisks ${ }^{*}$ and ${ }^{* *}$ denote statistical significance at the 5\% and $10 \%$ levels, respectively.

We infer the causal relationships between the variables using Granger causality tests. The results reported in Table 7 show that there is two-way long run causality between real effective exchange rate and trade balance. However, in the short run, there is no causal relationship among the variables.

\section{Conclusion}

This study examines the effect of FDI on the trade balance of Cote d'Ivoire. Using annual data covering the period from 1980 to 2017, we estimate the trade balance as a function of real effective exchange rate, domestic income and foreign direct investment. The cointegration test shows that there exists a long run relationship between the variables. The results show that domestic income, FDI and real effective exchange rate are among the driving factors of trade balance in the long run. A real depreciation of exchange rate improves trade balance, thus consistent with the Marshall-Lerner condition. An increase in foreign direct investment as a share of GDP is associated with a decrease in trade balance. Thus, foreign direct investment inflows to Cote d'Ivoire lead to a deterioration of the trade balance. In the short-run, both domestic income and real exchange rate have negative effects on the trade balance. An increase in domestic income drops the trade balance through increased demand for imports. Further, a real depreciation increases the trade surplus. On the contrary, foreign direct investment does not exert any significant effect on trade balance in the short run. Therefore, we can conclude that the increase in foreign direct investment inflows could be held responsible of the decrease in trade surplus over the recent period from 2012 to 2017. This finding may be explained by the sectoral allocation of foreign direct investment inflows which is predominated by service activities that are less exportable while requiring import inputs to be produced.

The implication of this study is that while attracting foreign investment in Cote d'Ivoire, government should consider their import content and encourage FDI with low import content in the long run. More precisely, FDI should be oriented towards sectors that use local goods and services to produce finish goods that might serve as substitute for imports in the country. In addition, policies should encourage FDI in industries with better export performance offsetting the increase in imports. In this study, we have considered the effect of aggregate FDI inflows on the trade balance of Cote d'Ivoire. It will be informative to examine the effect of the sectorial decomposition of FDI on the trade balance. This will indicate the sectors in which FDI inflows do have most significant improvement effects on the trade balance. We intend to investigate this issue in a future research.

\section{References}

Abd-El-Kader, E. S. M. (2013). Is the J-Curve Effect observable for Egypt Economy? Journal of Economic Cooperation and Development, 34(2), 91-118.

Adeniyi, O., Omisakin, O., \& Oyinlola, A. (2011). Exchange Rate and Trade Balance in West African Monetary Zone: Is There a J-Curve? The International Journal of Applied Economics and Finance, 5(3), 167-176. https://doi.org/10.3923/ijaef.2011.167.176

Akpansung, A. O., \& Babalola, S. J. (2013). Effects of Real Exchange Rate on Trade Balance: Empirical Evidence from Nigeria. Asian Journal of Empirical Research, 3(5), 605-617.

Alguacil, M. T., \& Orts, V. (2003). Inward Foreign Direct Investment and Imports in Spain. International Economic Journal, 17(3), 19-38. https://doi.org/10.1080/10168730300000002 
Anwar, S., \& Nguyen, L. P. (2011). Foreign Direct Investment and Trade: The Case of Vietnam. Research in International Business and Finance, 25(1), 39-52. https://doi.org/10.1016/j.ribaf.2010.05.004

Asiedu, E. (2002). On the Determinants of Foreign Direct Investment to Developing Countries: Is Africa Different? World Development, 30(1), 107-119. https://doi.org/10.1016/S0305-750X(01)00100-0

Athukorala, P., \& Menon, J. (1995). Developing with Foreign Investment: Malaysia. Australian Economic Review, 28(1), 9-22. https://doi.org/10.1111/j.1467-8462.1995.tb00873.x

Baharumshah, A. Z. (2001). The Effect of Exchange Rate on Bilateral Trade Balance: New Evidence from Malaysia and Thailand. Asian Economic Journal, 15(3), 291-312. https://doi.org/10.1111/1467-8381.00135

Bahmani-Oskooee, M. (1991). Is There a Long-Run Relation between the Trade Balance and the Real Effective $\begin{array}{lllll}\text { Exchange Rate of LDCs? Economics } & \text { Letters, 36(4), }\end{array}$ https://doi.org/10.1016/0165-1765(91)90206-Z

Bahmani-Oskooee, M., \& Gelan, A. (2012). Is there J-Curve Effect in Africa? International Review of Applied Economics, 26(1), 73-81. https://doi.org/10.1080/02692171.2011.619972

Bhatt, P. R. (2013). China's Exports and Foreign Direct Investment. Applied Econometrics and International Development, 13(2), 187-200.

Boga, S. (2019). Determinants of Foreign Direct Investment: A Panel Analysis for Sub-Saharan African Countries. Emerging Markets Journal, 9(1), 80-87. https://doi.org/10.5195/emaj.2019.175

Borensztein, E., De Gregorio, J., \& Lee, J. W. (1998). How does Foreign Direct Investment affect growth? Journal of International Economics, 45(1), 115-135. https://doi.org/10.1016/S0022-1996(97)00033-0

Brown, R. L., Durbin, J., \& Evans, J. M. (1975). Techniques for Testing the Constancy of Regression Relations over Time. Journal of the Royal Statistical Society, 37(2), 149-192. https://doi.org/10.1111/j.2517-6161.1975.tb01532.x

Chantha, H., Keo, K., \& Suttiprapa, C. (2018). An Empirical Analysis of Cambodia's Import Demand Function. Journal of Management, Economics, and Industrial Organization, 2(1), 1-12. https://doi.org/10.31039/jomeino.2018.2.1.1

Cheung, Y., \& Lai, K. S. (1993). Finite-Sample Sizes of Johansen's Likelihood Ratio Test for Cointegration. $\begin{array}{lllll}\text { Oxford Bulletin of Economics and } & \text { 313-328. }\end{array}$ https://doi.org/10.1111/j.1468-0084.1993.mp55003003.x

De Mello, L. (1997). Foreign Direct Investment in Developing Countries and Growth: A Selective Survey. The Journal of Development Studies, 34(1), 1-34. https://doi.org/10.1080/00220389708422501

De Mello, L. R., \& Fukasaku, K. (2000). Trade and Foreign Direct Investment in Latin America and Southeast Asia: Temporal Causality Analysis. Journal of International Development, 7, 903-924. https://doi.org/10.1002/1099-1328(200010)12:7<903::AID-JID695>3.0.CO;2-8.

Dritsaki, C., \& Stiakakis, E. (2014). Foreign Direct Investments, Exports, and Economic Growth in Croatia: A Time Series Analysis. Procedia Economics and Finance, 14, 181-190. https://doi.org/10.1016/S2212-5671(14)00701-1

Dritsaki, M., Dritsaki, C., \& Adamopoulos, A. (2004). A Causal Relationship between Trade, Foreign Direct Investment, and Economic Growth for Greece. American Journal of Applied Science, 1(3), 230-235. 10.3844/ajassp.2004.230.235

Engle, R. F., \& Granger, C. W. J. (1987). Cointegration and Error Correction: Representation, Estimation, and Testing. Econometrica, 55, 251-276. https://doi.org/10.2307/1913236

Gui-Diby, S. L. (2014). Impact of Foreign Direct Investment on Economic Growth in Africa: Evidence from Three Decades of Panel Data Analyses. Research in Economics, 68(3), 248-256. https://doi.org/10.1016/j.rie.2014.04.003

Guptar-Kapoor, A., \& Ramakrishnan, U. (1999). Is there a J-Curve? A New Estimation for Japan. International Economic Journal, 13, 71-79. https://doi.org/10.1080/10168739900000045

Hailu, Z. A. (2010). Impact of Foreign Direct Investment on Trade of African Countries. International Journal of Economics and Finance, 2(3), 122-134. https://doi.org/10.5539/ijef.v2n3p122

Helpman, E. (1984). A Simple Theory of International Trade with Multinational Corporations. Journal of Political Economy, 92(3), 451-471. https://doi.org/10.1086/261236 
Hoang, T. T., Wiboonchutikula, P., \& Tubtimtong, B. (2010). Does Foreign Direct Investment promote Economic Growth in Vietnam? ASEAN Economic Bulletin, 27(3), 295-311. https://doi.org/10.1355/ae27-3d

Hsiao, F. S. T., \& Hsiao, M. C. W. (2006). FDI, Exports, and GDP in East and Southeast Asia-Panel Data versus Time-Series Causality Analyses. Journal of Asian Economics, 17(6), 1082-1106. https://doi.org/10.1016/j.asieco.2006.09.011

Igue, N. N., \& Ogunleye, T. S. (2014). Impact of Real Exchange Rate on Trade Balance in Nigeria. African Development Review, 26(2), 347-3578. https://doi.org/10.1111/1467-8268.12086

Inder, B. (1993). Estimating Long-run Relationships in Economics: A Comparison of Different Approaches. Journal of Econometrics, 57, 53-68. https://doi.org/10.1016/0304-4076(93)90058-D

Jaiblai, P., \& Shenai, V. (2019). The Determinants of FDI in Sub-Saharan Economies: A Study of Data from 1990-2017. International Journal of Financial Studies, 7(3), 43. https://doi.org/10.3390/ijfs7030043.

Jayachandran, G., \& Seilan, A. (2010). A Causal Relationship between Trade, Foreign Direct Investment and Economic Growth for India. International Research Journal of Finance and Economics, 42, 74-88.

Johansen, S., \& Juselius, K. (1990). Maximum Likelihood Estimation and Inference on Cointegration with Applications to the Demand for Money. Oxford Bulletin of Econometrics and Statistics, 52, 169-210. https://doi.org/10.1111/j.1468-0084.1990.mp52002003.x

Kandiero, T., \& Chitiga, M. (2006). Trade Openness and Foreign Direct Investment in Africa. South African Journal of Economic and Management Sciences, 9(3), 355-370. https://doi.org/10.4102/sajems.v9i3.1093

Keho, Y. (2020). Foreign Direct Investment and Import Demand in Cote d'Ivoire. International Journal of Trade, Economics and Finance, 11(2), 24-31. https://doi.org/ 10.18178/ijtef.2020.11.2.661

Kiran, B. (2011). Causal Links between Foreign Direct Investment and Trade in Turkey. International Journal of Economics and Finance, 3(2), 150-158. https://doi.org/10.5539/ijef.v3n2p150

Kutan, A. M., \& Vuksic, G. (2007). Foreign Direct Investment and Export Performance: Empirical Evidence. Comparative Economic Studies, 49(3), 430-445. https://doi.org/10.1057/palgrave.ces.8100216

Kwiatkowski, D., Phillips, P. C. B., Schmidt, P., \& Shin, Y. (1992). Testing the Null Hypothesis of Stationarity against the Alternative of a Unit Root. Journal of Econometrics, 54(1-3), 159-178. https://doi.org/10.1016/0304-4076(92)90104-Y

Liew, V. K. S. (2004). Which Lag Length Selection Criterion Should We Employ? Economics Bulletin, 3(33), $1-9$.

Lin, A. (1995). Trade Effects of Foreign Direct Investment: Evidence for Taiwan with four ASEAN Countries. Review of World Economics, 131, 737-747. https://doi.org/10.1007/BF02707939

Liu, X., Burridge, P., \& Sinclair, P. J. N. (2002). Relationships between Economic Growth, Foreign Direct Investment and Trade: Evidence from China. Applied Economics, 34(11), 1433-1440. https://doi.org/10.1080/00036840110100835

Liu, X., Wang, C., \& Wei, Y. (2001). Causal Links between Foreign Direct Investment and Trade in China. China Economic Review, 12(2-3), 190-202. https://doi.org/10.1016/S1043-951X(01)00050-5

Lutkepohl, H. (1991). Introduction to Multiple Time Series Analysis. Germany: Springer-Verlag. https://doi.org/10.1007/978-3-662-02691-5

Markusen, J. R., \& Venables, A. J. (1998). Multinational Firms and the New Trade Theory. Journal of International Economics, 46(2), 183-203. https://doi.org/10.1016/S0022-1996(97)00052-4

Michael, E. O., \& Emeka, A. (2017). An Empirical Analysis of the Impact of Exchange Rate Devaluation on Trade Balance of Nigeria: Vector Error Correction Model Approach. Asian Journal of Economics, Business and Accounting, 3(3), 1-15. https://doi.org/1010.9734/AJEBA/2017/33355

Mohammad, M. A., \& Mahmoud, K. A. (2014). Foreign Direct Investment and Economic Growth Literature Review from 1994 to 2012. Procedia - Social and Behavioral Sciences, 129(15), 206-213. https://doi.org/10.1016/j.sbspro.2014.03.668

Neumayer, E., \& De Soysa, I. (2005). Trade Openness, Foreign Direct Investment and Child Labour. World Development, 33(1), 43-63. https://doi.org/10.1016/j.worlddev.2004.06.014

Nwaogu, U. G., \& Ryan, M. J. (2015). FDI, Foreign Aid, Remittance and Economic Growth in Developing 
Countries. Review of Development Economics, 19(1), 100-115. https://doi.org/10.1111/rode.12130

Ogbonna, B. C. (2016). Trade Balance Effect of Exchange Rate Devaluation in Benin Republic: The Empirical Evidence. IOSR Journal of Economics and Finance, 7(2), 33-43.

Ogundipe, A. A., Ojeaga, P., \& Ogundipe, O. M. (2013). Estimating the Long Run Effects of Exchange Rate Devaluation on the Trade Balance of Nigeria. European Scientific Journal, 9(25), 1-17.

Onafowora, O. (2003). Exchange Rate and Trade Balance in East Asia: Is there a J-Curve? Economics Bulletin, $5(18), 1-13$.

Onyeiwu, S., \& Shrestha, H. (2004). Determinants of Foreign Direct Investment in Africa. Journal of Developing Societies, 20(1-2), 89-106. https://doi.org/10.1177/0169796X04048305

Oyinlola, M. A., Omisakin, O. A., \& Adeniyi, O. A. (2013). An Empirical Re-examination of Exchange Rate-Trade Balance Nexus in Nigeria. African Journal of Economic Policy, 20(2), 123-141.

Pesaran, H., Shin, Y., \& Smith, R. J. (2001). Bounds Testing Approaches to the Analysis of Level Relationships. Journal of Applied Econometrics, 16(3), 289-326. https://doi.org/10.1002/jae.616

Phillips, P. C. B., \& Perron, P. (1988). Testing for a Unit Root in a Time Series Regression. Biometrika, 75(2), 335-346. https://doi.org/10.1093/biomet/75.2.335

Sajid, A., \& Nguyen, L. P. (2011). Foreign Direct Investment and Trade: The Case of Vietnam. Research in International Business and Finance, 25(1), 39-52. https://doi.org/10.1016/j.ribaf.2010.05.004

Shahzad, S. J. H., Ali, S., Rehman, M. U., \& Abbasi, F. (2015). Relationship between Remittances, Exports, Foreign Direct Investments and Growth in South Asia: A Panel Cointegration and Causality Analysis. Journal of Economic Cooperation and Development, 36(3), 93-122.

Soo, K. G., Wong, K. N., \& Tham, S. Y. (2013). Trade Linkages of Inward and Outward FDI: Evidence from Malaysia. Economic Modelling, 35, 224-230. https://doi.org/10.1016/j.econmod.2013.06.035

Tran, T. A. D., \& Dinh, T. T. B. (2014). FDI Inflows and Trade Imbalances: Evidence from Developing Asia. European Journal of Comparative Economics, 11(1), 147-169.

UNCTAD. (1999). World Investment Report: Foreign Direct Investment and the Challenge of Development. United Nations, New York and Geneva.

UNCTAD. (2005). Economic Development in Africa: Rethinking the Role of Foreign Direct Investment. United Nations, New York-Geneva.

Waheed, A., \& Jawaid, S. T. (2010). Inward Foreign Direct Investment and Aggregate Imports: Time Series Evidence from Pakistan. International Economics and Finance Journal, 5(1-2), 33-43.

Xuan, N. T., \& Xing, Y. (2008). Foreign Direct Investment and Exports: The Experience of Vietnam. Economics of Transition, 16(2), 183-197. https://doi.org/10.1111/j.1468-0351.2008.00321.x

Yousuf, M., Hussain, Z., \& Nisar, A. (2008). Economic Evaluation of Foreign Direct Investment in Pakistan. Pakistan Economic and Social Review, 46(1), 37-56.

Zhang, K. H., \& Song, S. (2000). Promoting Exports: The role of Inward FDI in China. China Economic Review, 11(4), 385-396. https://doi.org/10.1016/S1043-951X(01)00033-5

Ziramba, E., \& Chifamba, R. T. (2014). The J-Curve Dynamics of South African Trade: Evidence from the ARDL Approach. European Scientific Journal, 10(19), 346-358. https://doi.org/10.19044/esj.2014.v10n19p\%25p

\section{Copyrights}

Copyright for this article is retained by the author(s), with first publication rights granted to the journal.

This is an open-access article distributed under the terms and conditions of the Creative Commons Attribution license (http://creativecommons.org/licenses/by/4.0/). 